\title{
Trends in early mineralization of murine calvarial osteoblastic cultures: a Raman microscopic study
}

\author{
S. Stewart, ${ }^{1}$ D. A. Shea, ${ }^{1}$ C. P. Tarnowski, ${ }^{1}$ M. D. Morris, ${ }^{1 *}$ D. Wang, ${ }^{2}$ R. Franceschi, ${ }^{2}$ \\ D.-L. Lin ${ }^{3}$ and E. Keller ${ }^{3}$ \\ ${ }^{1}$ Department of Chemistry, University of Michigan, Ann Arbor, Michigan 48109, USA \\ ${ }^{2}$ School of Dentistry, University of Michigan, Ann Arbor, Michigan 48109, USA \\ ${ }^{3}$ Unit for Laboratory Animal Medicine, University of Michigan, Ann Arbor, Michigan 48109, USA
}

Received 16 October 2001; Accepted 24 March 2002

\begin{abstract}
The elucidation of early mineralization of bone is of great interest to the medical world. A clearer understanding of the initial bone formation processes can lead to information regarding the treatment and prevention of bone disorders and fractures and the manufacture of prosthetics. We exploited the mineralizing capabilities of bone cell cultures (osteoblast cultures) to monitor the earliest composition changes during mineral formation using Raman spectroscopy. We observed the first mineralization in 8-day-old osteoblasts and identified the mineral species as one that is very similar to that found in fetal bone tissue, a lightly carbonated apatite. Raman spectra show that carbonation, an indicator of bone maturity, appears at the first detectable stage of mineralization in osteoblasts, and increases over time. We also isolated single osteoblasts by growing them on fused-silica microscope slides. Not only did these cells exhibit abnormal growth patterns, but they also expressed a mineral composition different to a carbonated apatite. Raman spectra of this mineral species have spectral characteristics comparable to those of $\beta$-tricalcium phosphate. Copyright $\odot 2002$ John Wiley \& Sons, Ltd.
\end{abstract}

\section{INTRODUCTION}

Bone tissue is a not a simple material, but a complex integration of an extracellular matrix, principally type I collagen, and an inorganic mineral. ${ }^{1,2}$ Consequently, the process by which bone is formed is a complicated network of distinct mechanisms. Although the macroscopic properties of bone have been extensively investigated, the early steps in its mineralization are not well understood.

The most thermodynamically stable mineral in bone is a non-stoichiometric calcium phosphate arranged in an apatitic lattice very similar to hydroxyapatite (HAP). In mature bone the lattice contains significant levels of carbonate ions, substituted primarily into the phosphate sites (B-type carbonation), and small amounts of hydrogen phosphate. There may also be low substitution of other ions such as sodium and magnesium. In areas of abnormal mineralization, such as fatigue or repair, other minerals may be present. ${ }^{3}$

The two types of mineral deposition onto an organic extracellular matrix are intramembranous ossification (IO) and endochondral ossification (EO). ${ }^{3,4} \mathrm{EO}$ is found

*Correspondence to: M. D. Morris, Department of Chemistry, University of Michigan, Ann Arbor, Michigan 48109-1055, USA. E-mail: mdmorris@umich.edu

Contract/grant sponsor: NIH; Contract/grant number: P30 AR46024. throughout most of the body, and involves the mineralization of cartilaginous tissue. IO occurs with the mineralization of fibrous tissue. The calvaria, which are the flat bones that comprise the skull, undergo IO. The accepted theory is that osteoblast-derived cells are instrumental in the mechanisms of IO; they create an appropriate extracellular matrix environment for deposition of calcium and phosphate.

The nature of the calcium phosphate species formed during mineralization is a vital factor in the elucidation of the intricate mechanisms of early bone formation. Synthetic modeling studies have shown that in conditions mimicking a physiological environment, precursors to HAP such as octacalcium phosphate (OCP), amorphous calcium phosphate $(\mathrm{ACP})$ and $\beta$-tricalcium phosphate $(\beta$-TCP) are usually observed. ${ }^{3,5}$ Despite their easy isolation and characterization in synthetic systems, these precursor minerals have not been observed in bone tissue itself. ${ }^{5}$

The mechanism by which bone mineralizes has long been investigated by vibrational spectroscopy. ${ }^{6-10}$ The sensitivity of vibrational spectroscopy to both the mineral and organic elements of bone facilitates the study of both components and their interactions with each other. In the past, infrared spectroscopy has been preferred over Raman spectroscopy, owing to the interference of Raman spectra by fluorescence from biological specimens excited with visible lasers. This interference has been typically avoided by deproteinating 
specimens. ${ }^{11}$ More recently, Fourier transform (FT) Raman spectrometers have been employed to obtain Raman spectra from unaltered bone, minimizing fluorescence by exciting with near-infrared lasers. However, with the advent of charge-coupled device (CCD) array detectors, it has become possible to utilize dispersive Raman spectrometers with near-infrared laser excitation to collect quickly low-fluorescence spectra from biological specimens. Raman microspectroscopy offers added spatial resolution. The Raman spectrum of bone contains several bands which characterize mineral and matrix content. The phosphate $v_{1}$ symmetric stretch band is a prominent marker of mineral content, and other phosphate and carbonate modes are indicators of change in mineral composition and environment. The amide I, amide III and $\mathrm{CH}_{2}$ wags are typical markers for proteins in the extracellular matrix of bone. ${ }^{12}$

The literature on the application of vibrational spectroscopy to mineralized tissues was recently reviewed. ${ }^{13}$ Infrared spectroscopy dominates the literature, and has been employed to measure the mineral and collagen in the bone itself ${ }^{12,14,15}$ in addition to non-collagenous proteins found in the extracellular matrix and believed to be heavily involved in the mineralization process. ${ }^{16,17}$ Raman spectroscopy and imaging have been used to study mineralization gradients in areas of growth and repair of normal and abnormal tissue. ${ }^{18,19}$ One problem, however, with the study of bone tissue, is the fact that bone is continuously undergoing mineralization in both formation and remodeling. As a consequence, there are always multiple cell types in varying degrees of differentiation and maturity present in the tissue. This inherent heterogeneity presents a major difficulty in studying the mechanisms by which bone is formed. An alternative system that has been used to study bone mineralization is the osteoblast cell culture. Osteoblasts are cells involved with bone formation. They have been found to secrete a type I collagen-containing extracellular matrix which, under specific conditions, calcifies. ${ }^{1,4}$ The absence of cell types other than osteoblasts has the advantage of providing a more homogeneous crystal population at a specific time, as there are no competing cellular activities. Previous reports have shown that a deposition of poorly crystalline apatite occurs in osteoblast cultures in an analogous manner to in vivo calcification..$^{20-22}$ These properties make osteoblast cultures important bone mineralization models that can be well used by vibrational spectroscopists.

Rey and co-workers investigated calcium phosphate crystals deposited in the organic matrix synthesized by chick bone osteoblasts in culture after 30, 40 and 60 days, using FTIR spectroscopy. ${ }^{23,24}$ Their data revealed that the solid inorganic calcium phosphate phase in the cells consisted of a very poorly crystalline apatite with low carbonate content and containing acid phosphate groups. After 30 days the nature of the mineral formed was similar to that found in late embryonic chick and early postnatal chick bone. Although the concentrations of carbonate and hydrogen phosphate ions were lower, and their change with time was slower than those in vivo, the general overall pathway of maturation was similar in cell culture to that observed in bone tissue. The same group also found that the mineral in protein-free chicken osteoblast cultures (8 and 60 days old) was characteristic of the apatite crystals in embryonic chick bone in vivo, with the 60-day-old osteoblasts showing a higher order of arrangement of ion constituents. ${ }^{25}$ In all of these investigations only one mineral phase was observed.

This paper presents evidence of a carbonated apatiticlike mineral formed in mouse calvarial osteoblasts at the earliest stages of formation and its development over 14 days. We also present spectroscopic evidence for another mineral deposited in osteoblasts grown on fused-silica microscope slides in order to isolate the cells. In a departure from the protocols of many laboratories, we did not isolate the mineral crystals from the protein.

Our data sets contain 100 spectra each. To handle the data sets, we use established multivariate techniques, usually factor analysis (FA). FA exploits the covariance of large data sets to reduce the data to more manageable numbers of significant factors. ${ }^{26}$ As a result, changes in the background can be distinguished from changes in the Raman spectra. The simplification of large data sets to a few non-noise components allows the observation of small changes in the spectral features that might otherwise go unnoticed. ${ }^{12}$ FA removes from the spectra much of the fluorescence background and noise, and separates the mineral and the protein components' spectral signatures.

\section{EXPERIMENTAL}

\section{Osteoblast cell cultures}

The osteoblastic cell line was derived from mouse calvaria. MC3T3-E1 cells are a clonal cell line that retain most properties of primary osteoblast cultures including the ability to express a series of osteoblast-related gene products and form a highly mineralized extracellular matrix containing multiple cell layers. ${ }^{27,28}$ In one experiment (cell culture 1), MC3T3-E1 cells were grown in a conventional manner. Cultured in standard polystyrene culture dishes in $\alpha$ Minimal Essential Medium ( $\alpha$-MEM), cells were fed $10 \%$ Fetal Bovine Serum (FBS), $50 \mu \mathrm{g} \mathrm{ml}^{-1}$ ascorbic acid and $10 \mathrm{~mm}$ $\beta$-glycerophosphate $\left(\beta\right.$-GP), which induces mineralization. ${ }^{29}$ Cells were supplied with the complete medium every 2 days up to day 14 . They were stored in phosphate-buffered saline in a refrigerator until use, when they were removed from the culture dish, dried and placed on a UV-grade fused-silica microscope slide (Esco Products) for Raman measurements.

In a second experiment (cell culture 2), a small number of osteoblasts cultured from the MC3T3-E1 cell line were deposited directly on UV-grade fused-silica slides (Esco Products) and grown in a medium containing $\alpha$-MEM supplemented with $20 \%$ FBS, $10 \mathrm{~mm} \quad \beta$-GP, $50 \mu \mathrm{g} \mathrm{ml}^{-1}$ 
L-ascorbic acid and antibiotics. The cells were isolated from the medium at 3, 6, 9 and 12 day intervals.

\section{Raman spectroscopy}

The Raman microscope instrumentation and design have been described previously. ${ }^{19}$ In brief, the specimen was placed on a motorized $X-Y$ stage (New England Affiliated Technologies) mounted on a modified epi-fluorescence microscope (Olympus BH-2). A 785 nm laser (SDL, $200 \mathrm{~mW}$ output) was focused on the specimen through a $10 \times$, 0.5 N.A. objective (Fluar Series, Zeiss). Raman scattered light was collected using epi-illumination and focused into an axial-transmissive spectrograph (Kaiser Optical Systems, Holospec $f / 1.8 \mathrm{I}$ ) and dispersed on to a back-thinned, liquid nitrogen-cooled CCD camera (Roper Scientific). The spectrograph was equipped with a $25 \mu \mathrm{m}$ slit that provided a spectral resolution of $3-4 \mathrm{~cm}^{-1}$.

For Raman spectroscopy of cell culture 1, mineralization was fairly extensive across the cell cultures. In this case, transects (lines of 100 point spectra) were acquired over a $400 \mu \mathrm{m}$ region at $8 \mu \mathrm{m}$ spatial resolution ( $4 \mu \mathrm{m}$ steps) using an integration time of 5 min per point. For cell culture 2 , there were so few cells that transects were not practical. Individual point spectra of isolated cells were collected utilizing an integration time of $20 \mathrm{~min}$.

\section{Data analysis}

Interpretation of the data was carried out both by visually inspecting point spectra and by analysis of transect data using multivariate methods. Grams32 (Galactic Industries) and MATLAB 5.2 (Mathworks) software packages were employed, using both vendor-supplied and locally written scripts. For both point and transect spectra, the data were corrected for dark current and background signal. The transect data sets were divided into two spectral subregions and exploratory factor analysis (FA) was performed as described in a previous paper. ${ }^{30}$ Briefly, eignenanalysis was performed to reduce the data to a few eigenvectors that represented most of the variance in the data set. These eigenvectors were then linearly combined (i.e. rotated) to give factors and scores that have physical meaning. Rotated factors represent Raman spectra of chemical species. The corresponding scores depict where in the data set that factor is present; the magnitude of a score is an indicator of that factor's contribution to the spectrum. ${ }^{12}$

To calculate carbonate: phosphate ratios, the area of the $1072 \mathrm{~cm}^{-1}$ band was used as a measure of carbonate content and that of the $960 \mathrm{~cm}^{-1}$ band as a measure of phosphate content. The regions of interest were baseline corrected with a fourth-order polynomial, before integration.

\section{RESULTS AND DISCUSSION}

The two cell cultures underwent very different growth patterns. In the cells grown conventionally (cell culture 1) and supplemented with $\beta$-GP, a white, opaque growth on the surface was visible to the eye after 8 days. This layer appeared to increase in density and thickness over time. In the cells grown on fused-silica slides (cell culture 2) supplemented with $\beta$-GP, evidence of mineral was not visible to the eye, and growth was extremely retarded. Individual cells and small aggregates of cells were observed, and there was no visible distinguishing characteristic to determine cells that had undergone mineralization and those that had not.

\section{Raman spectroscopy}

One of the principal issues hindering the study of vibrational spectra of early bone is associated with the organic matrix. In infrared spectroscopy the high levels of matrix obscure signal rising from small amounts of mineral and in Raman spectroscopy the fluorescence associated with the organic matrix add further problems. To combat the effects of protein interference, some workers have studied calcium phosphate crystals isolated from the extracellular matrix by using protein decomposition reagents such as hydrazine and hydrogen peroxide. Although this method seems to have improved the Raman and infrared spectra, there are concerns that the treatments may affect the structural or chemical properties of the mineral, ${ }^{5}$ and detectable spectral shifts and loss of carbonate bands in the Raman spectra of deproteinated bone have been reported. ${ }^{31}$ The employment of FA has enabled us to investigate the cells without chemical treatment. Although osteoblast cultures are considered more homogeneous than bone tissue, we collected transects in order to observe the distribution of mineral and protein in the culture.

The phosphate species present in bone mineral is characterized principally by the phosphate stretch $\left(v_{1}\right)$ spectral position, which ranges in the $950-963 \mathrm{~cm}^{-1}$ region. Previous work indicated three general mineral environments and their corresponding phosphate $v_{1}$ band positions: a carbonated apatite (ca. $956 \mathrm{~cm}^{-1}$ ), a disordered calcium phosphate (ca. $950 \mathrm{~cm}^{-1}$ ) and a non-carbonated, more crystalline apatite (ca. $\left.962 \mathrm{~cm}^{-1}\right){ }^{12}$ In areas of dynamic change and rapid growth, several mineral environments may be present. The marker band for the presence of precursor minerals is also the $v_{1}$ phosphate mode. Table 1 contains a number of examples of these minerals and the Raman shift of their phosphate $v_{1}$ mode. ${ }^{5,32}$ The other principal Raman markers for bone are the phosphate asymmetric stretch $\left(v_{3}\right.$, ca. $1030 \mathrm{~cm}^{-1}$ ) and the B-type carbonate symmetric stretch $\left(v_{1}\right.$, ca. $1070 \mathrm{~cm}^{-1}$ ), the latter of which is used mainly as a general marker of bone maturity or health. Collagen marker bands for the Raman spectrum are amide I (ca. $1660 \mathrm{~cm}^{-1}$ ), amide III (ca. $1250 \mathrm{~cm}^{-1}$ ), and the $\mathrm{CH}_{2}$ wag at ca. $1450 \mathrm{~cm}^{-1}$.

\section{Cell culture 1}

We observed no Raman signal from cell culture 1 until day 6 . Prior to then, Raman spectra of the control and $\beta$-GP fed cell cultures were essentially featureless except for a large, broad 
Table 1. Band position of the phosphate $\nu_{1}$ mode in the Raman spectrum of several hydroxyapatite precursors

\begin{tabular}{llc}
\hline Mineral species & \multicolumn{1}{c}{ Structure } & $\begin{array}{c}\text { Wave number of } \\
\text { phosphate } v_{1} \\
\text { mode } / \mathrm{cm}^{-1} \\
(\text { Refs 5, 32) }\end{array}$ \\
\hline $\begin{array}{l}\text { Amorphous calcium phosphate (ACP) } \\
\text { Octacalcium phosphate (OCP) }\end{array}$ & $\begin{array}{l}\mathrm{Ca}_{9}\left(\mathrm{PO}_{4}\right)_{6} \cdot x \mathrm{H}_{2} \mathrm{O} \\
\mathrm{Ca}_{8} \mathrm{H}_{2}\left(\mathrm{PO}_{4}\right)_{6} \cdot 5 \mathrm{H}_{2} \mathrm{O}\end{array}$ & 952 \\
$\begin{array}{l}\text { Hydroxyapatite (HAP) } \\
\beta \text {-Tricalcium phosphate }(\beta \text {-TCP) }\end{array}$ & $\mathrm{Ca}_{10}\left(\mathrm{PO}_{4}\right)_{6}(\mathrm{OH})_{2}$ & 957 \\
Dicalcium phosphate dihydrate (DCPD) & $\mathrm{Ca}_{3}\left(\mathrm{PO}_{4}\right)_{2}$ & 960 \\
\hline $\mathrm{CaHPO}_{4} \cdot 2 \mathrm{H}_{2} \mathrm{O}$ & 970 \\
\hline
\end{tabular}

envelope due to the silica in the microscope slide. The absence of bands due to protein, lipids and nuclear material and the relatively high intensity of the substrate signal indicate the thinness of the cell layer before day 6 . At day 6 the spectrum of the control cells (not shown) also contains protein bands with a signal-to-noise ratio $(\mathrm{S} / \mathrm{N})$ markedly lower than that of the cells supplemented with $\beta$-GP. This may be a result of the different Raman cross-sections of the two specimens, due to low cell growth at day 6 .

At day 6 there is no evidence of mineral formation. Evidence of mineralization first appears in the $\beta$-GP-fed osteoblasts at day 8 . No mineralization was observed in the control cells; this was expected as without a phosphate source, mineral cannot be formed. Figure 1 compares example raw spectra of $\beta$-GP-supplemented cell culture 1 at day 6 (a, protein only) and at day $8(\mathrm{~b}$, apatitic mineral and protein).
FA of Raman transects of 6-day-old, $\beta$-BP fed osteoblasts revealed two principal factors: one, a generally featureless, background signal, and the other, the contribution from the extracellular matrix. These factors contain Raman spectral signatures. Figure 2 shows the matrix factors in both spectral subregions. The principal band positions and their assignments are presented in Table 2, and are characteristic of protein. They are in good agreement with previous reports of the proteinaceous matrix of bone. ${ }^{19,33,34}$ The scores corresponding to the factors in Fig. 2 are not shown, as they contain no relevant information. The nature of cell cultures is that they are a random amalgamation of cells across a surface, with no spatially distinguishable components.

Figure 3 shows the factor describing the mineral contribution in 8-day-old, $\beta$-GP-fed osteoblasts. Three factors in the $750-1250 \mathrm{~cm}^{-1}$ range reflect the presence of a protein, a mineral and a fluorescent background. The protein factor (not

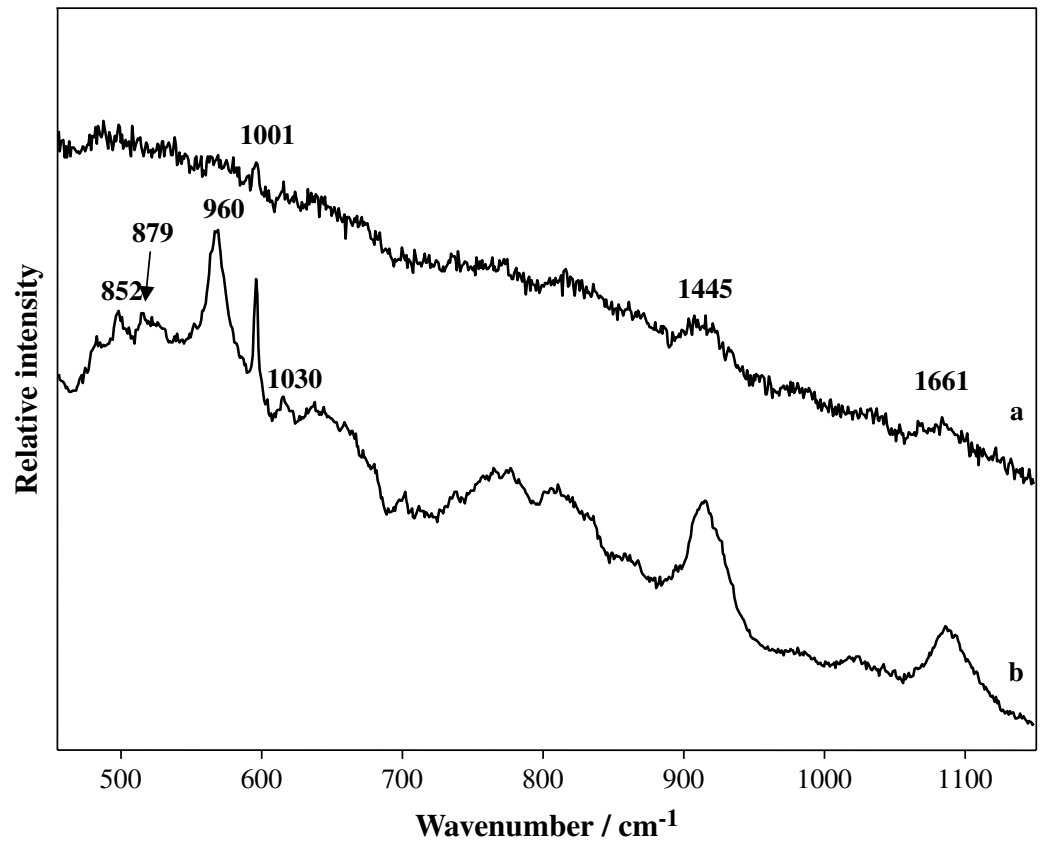

Figure 1. Raw Raman spectra of $\beta$-GP-fed cell culture 1 (a) 6 days old, showing protein bands, and (b) 8 days old, showing bands due to protein and an apatitic mineral. 


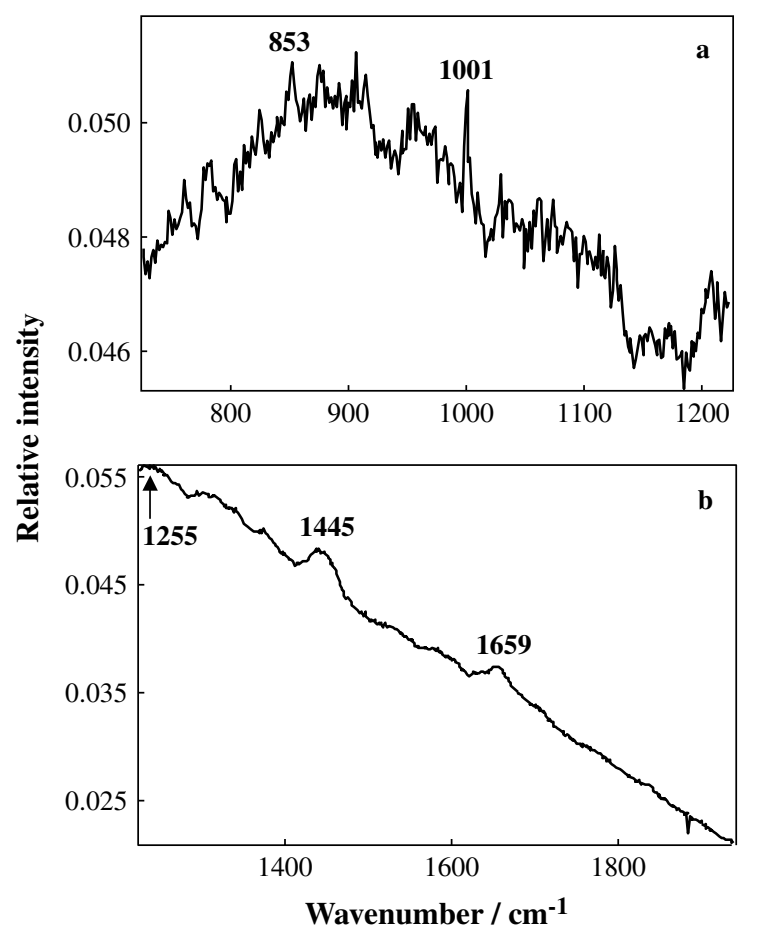

Figure 2. Factors describing cell culture 1, exhibiting typical growth at day 6 . Spectral regions (a) $750-1250 \mathrm{~cm}^{-1}$ and (b) $1250-1800 \mathrm{~cm}^{-1}$ contain bands that are characteristic of the extracellular matrix.

Table 2. Raman spectral interpretation of extracellular matrix in day 6 osteoblasts, exhibiting typical growth and mineralization

\begin{tabular}{cl}
\hline Wave number $/ \mathrm{cm}^{-1}$ & \multicolumn{1}{c}{ Assignment } \\
\hline 852 & C-C proline, hydroxyproline \\
879 & C-C hydroxyproline \\
1001 & Phenylalanine ring breathing \\
1255 & Amide III \\
1445 & $\mathrm{CH}_{2}$ wag \\
1660 & Amide I \\
\hline
\end{tabular}

shown) contains the same bands described in the day 6 data at a higher $S / N$. The presence of apatitic mineral is represented by the high-intensity band at $960 \mathrm{~cm}^{-1}$, corresponding to the $v_{1}$ phosphate vibration of a poorly carbonated apatite-like mineral. The other very weak bands present in the spectrum are the phosphate $v_{3}\left(1030 \mathrm{~cm}^{-1}\right)$ and the B-type carbonate $v_{1}\left(1072 \mathrm{~cm}^{-1}\right)$. The $1072 \mathrm{~cm}^{-1}$ band is very weak, indicating the low level of carbonate in the mineral. The broad background under the phosphate envelope is most likely a small protein fluorescence contribution occurring with the same distribution across the transect as the mineral. A similar mineral species was observed with Raman spectroscopy in the calvaria of young mice. ${ }^{35}$ Similarly, Rey et al. found that the infrared spectra of chicken osteoblasts contained

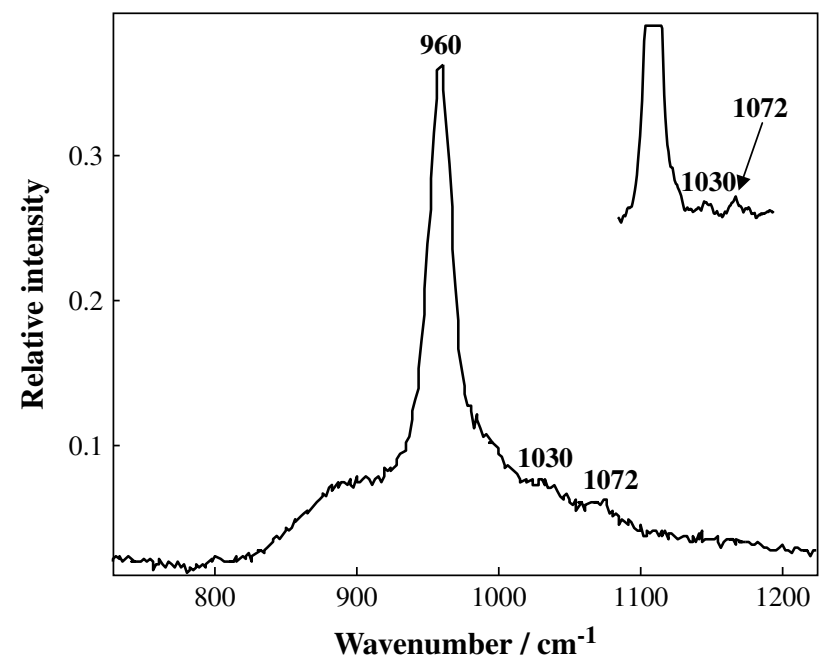

Figure 3. Mineral factor illustrating a lightly carbonated apatitic mineral present in $\beta$-GP-fed cell culture 1 . The inset highlights the 1030 and $1072 \mathrm{~cm}^{-1}$ bands.

Table 3. Area ratios of carbonate $v_{1}\left(1072 \mathrm{~cm}^{-1}\right)$ and phosphate $v_{1}\left(960 \mathrm{~cm}^{-1}\right)$ bands in mineralized osteoblasts exhibiting typical growth at $8,10,12$ and 14 days

\begin{tabular}{ccc}
\hline Osteoblast age/days & $\begin{array}{c}\text { Ratio of band areas } \\
\mathrm{CO}_{3}{ }^{2-} / \mathrm{PO}_{4}{ }^{3-}\end{array}$ & Change/\% \\
\hline 8 & 0.017 & \\
10 & 0.020 & +13 \\
12 & 0.021 & +8 \\
14 & 0.022 & +3 \\
\hline
\end{tabular}

bands also contained in the infrared spectra of chicken bone tissue. ${ }^{23}$

For the 10-12- and 14-day-old osteoblasts, the same apatite environment was the only one observed. The Raman band representing the mineral component in each of the cell cultures lies between 958 and $960 \mathrm{~cm}^{-1}$, and there is a very weak signal due to carbonate in each of the spectra. The lack of evidence for precursor mineral species such as OCP in our Raman spectra was in agreement with the results of other research groups. ${ }^{23-25}$ The Raman spectrum due to the extracellular matrix did not change over time.

The maturation of the mineral in bone is indicated by the changes in the phosphate and carbonate modes. In bone tissue it is established that an increase in carbonate occurs with increasing mineralization, ${ }^{7,9}$ and studies have shown that the carbonate in osteoblast cultures exhibits similar maturation characteristics, although at a slower rate. ${ }^{25}$ Table 3 details the ratio of the carbonate $v_{1}\left(1072 \mathrm{~cm}^{-1}\right)$ and phosphate $v_{1}\left(960 \mathrm{~cm}^{-1}\right)$ band areas for the mineralized cells, a recognized measure of mineral maturity. ${ }^{12}$ Despite the low $\mathrm{S} / \mathrm{N}$ of the spectra, the slight increase in carbonation (with respect to the phosphate band) is evident. 


\section{Cell culture 2}

By growing the cells directly on fused-silica slides we were able to decrease the degree of cell differentiation and therefore isolate single and small clusters of osteoblasts. Since the cell growth on the fused-silica slides was less than that of the previous cultures, it was not possible to take transect data. Single-point spectroscopy with long integration times was instead used to achieve an acceptable $\mathrm{S} / \mathrm{N}$. Mineralization in these cells was evident in the day 6 cells, slightly earlier than in the first set of cell cultures. These cells showed radically different spectra to those grown conventionally, with the band representing the mineral vibration red-shifted $\left(975 \mathrm{~cm}^{-1}\right)$ with respect to the expected hydroxyapatitic mineral. Additionally, the phosphate peak is markedly broader than that expected for a hydroxyapatitic mineral.

The Raman spectra of cell culture 2 control osteoblasts and those supplemented with $\beta$-GP on days 3, 6 and 9 are shown in Fig. 4. The increase in the $975 \mathrm{~cm}^{-1}$ band from day 6 , along with a concomitant increase in a band at $1478 \mathrm{~cm}^{-1}$, are evident. The presence of the sharp phenylalanine band at $1001 \mathrm{~cm}^{-1}$ and its correlation with the mineral spectrum confirm that this new mineral band is found within the
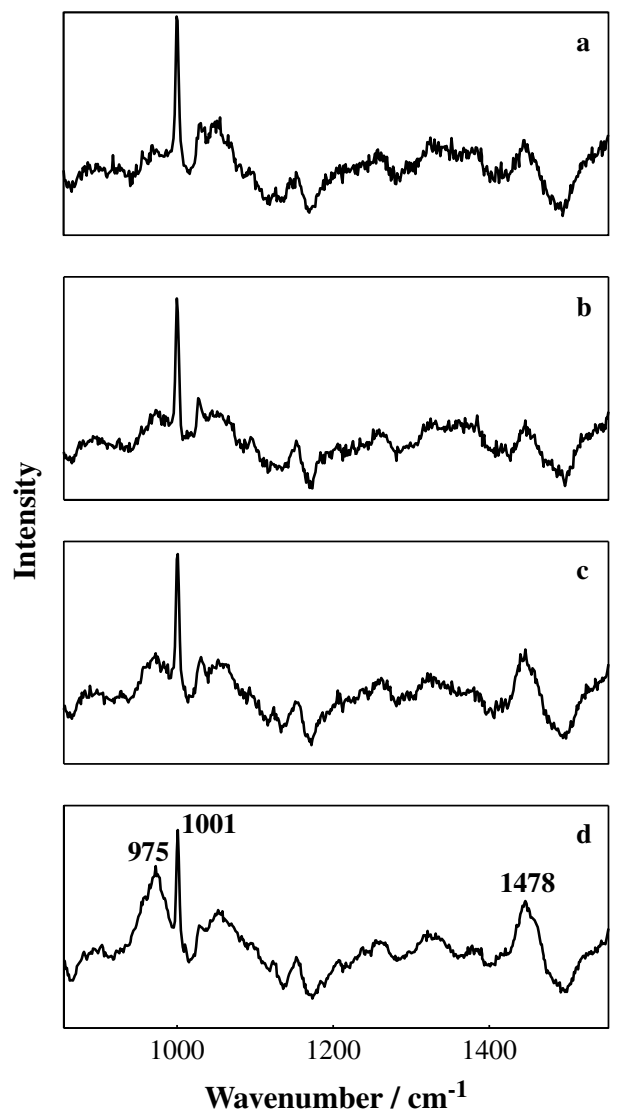

Figure 4. Raman spectra of cell culture 2, exhibiting atypical growth: (a) control osteoblasts compared with

$\beta$-GP-supplemented cells over (b) 3, (c) 6 and (d) 9 days. cells, and is not artifactual. Spectra taken of the control cell culture yielded only cellular bands, while spectra taken of the residual media surrounding the cells on the microscope slide exhibited no Raman scattered light (not shown).

The day 12 cell culture showed very poor Raman signal. The cellular material spectral signature was weak at best and no mineral signal could be observed. This was a surprise to us, as we expected to see either a decrease in the $975 \mathrm{~cm}^{-1}$ band and a correlated increase at $960 \mathrm{~cm}^{-1}$ resulting from a conversion of the new mineral to an apatitic lattice, or an increase in the $975 \mathrm{~cm}^{-1}$ stemming from the continued expression of the atypical mineral. The low cell signal combined with a dramatic lack of mineral signal led us to believe the cells had died, and that any mineral expressed had redissolved in the medium.

The spectra obtained from these cells indicate that the mineral present is not apatitic. The band maximum is shifted by more than $15 \mathrm{~cm}^{-1}$ from the apatitic $v_{1}$ wavenumber and is markedly broader than would be expected, even in a biological system, where perfectly stoichiometric mineral is not expected. The appearance of a strong shoulder to lower energy is indicative of multiple peaks comprising the observed band contours. While assignment of the mineral type present in the cell culture cannot be definitive, after comparison of the mineral band with assignments for bands of known minerals (ACP, OCP, HAP, $\beta$-TCP and DCPD), and confirmation with spectra of candidate minerals obtained in our laboratory, we believe that the most likely candidate is $\beta$-TCP. In Table 1 , the characteristic phosphate $v_{1}$ modes of several mineral species are observed to be in a different spectral region to that observed in cell culture 2. $\beta$-TCP has two bands in the $950-970 \mathrm{~cm}^{-1}$ range, narrowly separated. Figure 5 shows the comparison between the spectrum of pure crystalline $\beta$-TCP (a) and the phosphate region of the day 9 spectrum of the second set of cell cultures (b). It is likely that in the cell cultures, $\beta$-TCP is of poor crystallinity, with regions of varying growth and contaminant incorporated throughout the culture. This, combined with the biological broadening of the two $\beta$-TCP peaks, provides a plausible explanation for the width and shape of the mineral band present.

The expression of an atypical mineral Raman spectrum and apparent cell death at day 12 imply that the cells were exposed to some ingredient that proved toxic. We attribute the apparent appearance of $\beta$-TCP to an excess of $\beta$-GP relative to the number of cells grown. It has been reported that high concentrations of $\beta$-GP contribute to cell apoptosis, ${ }^{22}$ and we believe that the small number (and therefore density) of cells exposed them to an abnormally high concentration of $\beta$-GP per cell.

Bulk studies have shown that the removal of $\beta$-TCP occurs through surface interactions of bone-absorbing cells (osteoclasts) with $\beta$-TCP. In addition, $\beta$-TCP has been shown to resorb more easily than $\mathrm{HAP}^{36}$ and consequently crystallites of $\beta$-TCP would be quickly removed in any 


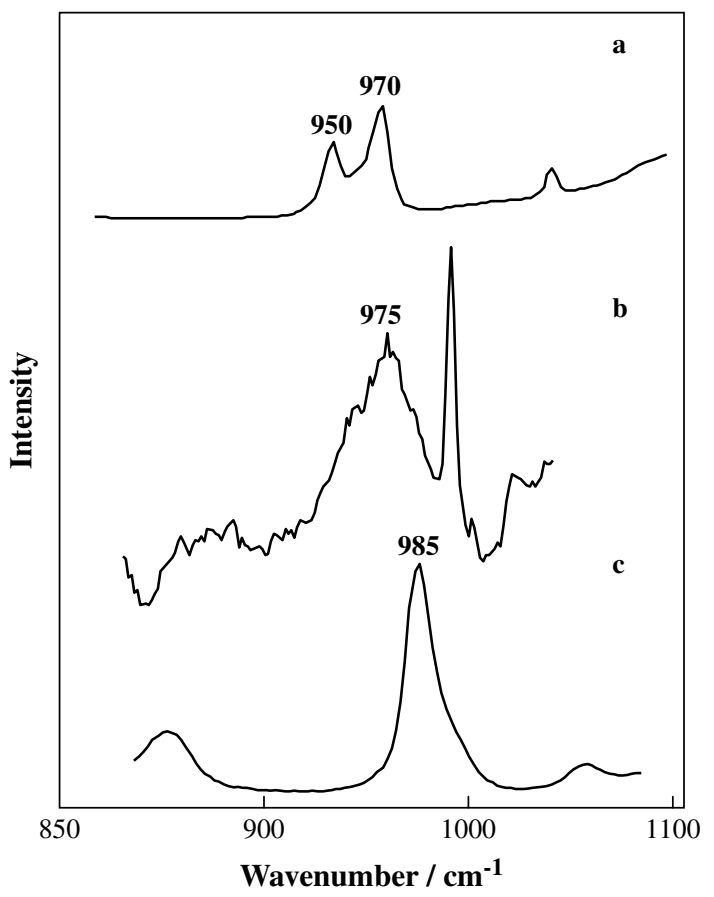

Figure 5. Phosphate $v_{1}$ region of the Raman spectra of (a) crystalline $\beta$-TCP, (b) $\beta$-GP-fed cell culture 2, day 9 and (c) crystalline DCPD. Spectra are offset for clarification.

resorption process. ${ }^{37}$ If $\beta$-TCP were an intermediate during HAP formation, it is possible that its resorption and conversion to another crystal species are faster than can be measured with current techniques. The absence of osteoclasts from the cell cultures and the obvious retardation of growth and mineralization in these cultures allowed us to observe a mineral species other than HAP. Such a rich phosphate environment may have caused the expression of the kinetic phosphate product ( $\beta$-TCP) rather than the thermodynamic phosphate product (HAP).

\section{CONCLUSION}

Since it has been shown that much of the information that is determined through analysis of osteoblast cultures can be transferred directly to bone research, the research presented here continues to analyze the question of what mineral is formed first during the early stages of mineralization.

Raman spectroscopy of conventionally grown mouse calvarial osteoblasts exhibited evidence of mineralization at day 8 and revealed a mineral species with bands characteristic of a poorly carbonated apatite similar to that found in young mouse calvarial tissue. The weakness of the carbonate signal indicated the immaturity of the mineral, and the slight increase in area of the carbonate band from day 8 to day 14 mirrored the behavior of the carbonate signal in young mouse bone tissue.
Isolation of the osteoblasts during growth was achieved by culturing a small number of cells directly on to fusedsilica slides and inducing mineralization in the conventional manner. These cells exhibited atypical growth and mineralization which we were able to observe spectroscopically. The mineral formed was best explained as a $\beta$-TCP-like mineral, a mineral species not normally expected during the mineral growth process, but suspected to be a precursor for some synthetic hydroxyapatites.

\section{Acknowledgment}

We thank the University of Michigan Bone Research Center through NIH grant P30 AR46024 for financial support.

\section{REFERENCES}

1. Kaplan FS, Hayes WC, Keaveny TM, Boskey A, Einhorn TA, Iannotti JP. In Orthopaedic Basic Science, Simon SR (ed.). American Academy of Orthopaedic Surgeons: Rosemont, 1994; 127-184.

2. Nancollas GH, Lore M, Perez L, Richardson C, Zawacki SJ. Anat. Rec. 1989; 224: 234.

3. Johnsson MSA, Nancollas GH. Crit. Rev. Oral Biol. Med. 1992; 3: 61.

4. Gorski JP. Crit. Rev. Oral Biol. Med. 1998; 9: 201.

5. Sauer GR, Zunic WB, Durig JR, Wuthier RE. Calcif. Tissue Int. 1994; 54: 414.

6. Timlin JA, Carden A, Morris MD, Bonadio JF, Hoffler CEI III, Kozloff KM, Goldstein SA. J. Biomed. Opt. 1999; 4: 28.

7. Rey C, Renugopalakrishnan V, Collins B, Glimcher MJ. Calcif. Tissue Int. 1991; 49: 251.

8. Rey C, Hina A, Tofighi A, Glimcher MJ. Cells Mater. 1995; 5: 345.

9. Boskey A, Plashko N, Doty SB, Mendelsohn R. Cells Mater. 1992; 2: 209.

10. Mendelsohn R, Hassankhani A, DiCarlo E, Boskey A. Calcif. Tissue Int. 1989; 44: 20.

11. Penel G, Leroy G, Rey C, Bres E. Calcif. Tissue Int. 1998; 63: 475.

12. Timlin JA, Carden A, Morris MD. Appl. Spectrosc. 1999; 53: 1429.

13. Carden A, Morris MD. J. Biomed. Opt. 2000; 5: 259.

14. Kim H-M, Rey C, Glimcher MJ. J. Bone Miner. Res. 1995; 10: 1589.

15. Rey C, Miquel JL, Facchini L, Legrand AP, Glimcher MJ. Bone 1995; 16: 583.

16. Boskey AL, Gadaleta S, Gundberg C, Doty SB, Ducy P, Karsenty G. Bone 1998; 23: 187.

17. Bohic S, Rohanizadeh R, Touchais S, Godard A, Daculsi G, Heymann D. J. Bone Miner. Res. 1998; 13: 1619.

18. Morris MD, Tarnowski CP, Timlin JA, Carden A, Dreier JL, Ignelzi MA Jr, Lin D-L, Keller ET. Proc. SPIE 2000; 3918: 2.

19. Timlin J, Carden A, Morris MD. Anal. Chem. 2000; 72: 2229.

20. Ecarot-Charrier B, Shepard N, Charette G, Grynpas M, Glorieux FH. Bone 1988; 9: 147.

21. Gerstenfeld LC, Chipman SD, Glowacki J, Lian JB. Dev. Biol. 1987; 122: 49.

22. Stanford CM, Jacobson PA, Eanes ED, Lembkes LA, Midura RJ. J. Biol. Chem. 1995; 270: 9420.

23. Rey C, Kim H-M, Gerstenfeld L, Glimcher MJ. J. Bone Miner. Res. 1995; 10: 1577.

24. Rey C, Kim H-M, Gerstenfeld L, Glimcher MJ. Connect. Tissue Res. 1996; 35: 343.

25. Kuhn LT, WuY, ReyC, Gerstenfeld LC, Grynpas MD, Ackerman JL, Kim H-M, Glimcher MJ. J. Bone Miner. Res. 2000; 15: 1301.

26. Adams MJ. Chemometrics in Analytical Spectroscopy. Royal Society of Chemistry: Cambridge, 1995. 
27. Franceschi RT, Iyer BS. J. Bone Miner. Res. 1992; 7: 235.

28. Franceschi RT, Iyer BS, Cui Y. J. Bone Miner. Res. 1994; 9: 843.

29. Chung C-H, Golub EE, Forbes ETT, Shapiro IM. Calcif. Tissue Int. 1992; 51: 305.

30. Shaver JM, Christensen KA, Pezzuti JA, Morris MD. Appl. Spectrosc. 1998; 52: 259.

31. Walters MA, Leung YC, Blumenthal NC, LeGeros RZ, Konsker KA. J. Inorg. Biochem. 1990; 39: 193.

32. Penel G, Leroy N, Van Landuyt $P$, Flautre $B$, Hardouin $P$, Lemaitre J, Leroy G. Bone 1999; 25: 81S.
33. Wuthier RE. Connect. Tissue Res. 1989; 22: 27.

34. Penel G, Leroy G, Bres E. Appl. Spectrosc. 1998; 52: 312.

35. Tarnowski CP, Ignelzi MA Jr, Morris MD. J. Bone Miner. Res. in press.

36. Denissen H, Mangano C, Venini G. In Hydroxylapatite Implants, Dennisen H (ed.). Piccin: Padua, 1985.

37. Doi $Y$, Iwanaga H, Shibutani T, Moriwaki Y, Iwayama Y. J. Biomed. Mater. Res. 1999; 47: 424. 